\title{
NILAI-NILAI DALAM KESENIAN HADRAH DI KOTA PONTIANAK
}

\author{
Regaria Tindarika \\ Program Studi Pendidikan Seni Pertunjukan, FKIP, Universitas Tanjungpura, Jl. Prof. Dr. H.Hadari Nawawi \\ e-mail korespondensi : regaria.tindarika@fkip.untan.ac.id
}

\begin{abstract}
Abstrak : Penelitian ini mendeskripsikan nilai-nilai yang terkandung dalam kesenian Hadrah di Kota Pontianak, Kalimantan Barat. Hadrah erat kaitannya dengan kesenian bernapaskan islami karena syair yang dilantunkan berisi puji-pujian terhadap Sang Pencipta dan Nabi Muhammad Shallallahu Alaihi Wasallam serta nasihat-nasihat. Menggunakan metode penelitian kualitatif dengan pendekatan antropologi. Teknik pengumpulan data menggunakan wawancara, observasi, studi pustaka serta di uji keabsahan datanya dengan cara perpanjang pengamatan dan triangulasi. Berdasarkan analisis data dapat disimpulkan bahwa kesenian Hadrah telah ada di kota Pontianak sejak abad ke-17. Kesenian ini dibawa oleh pedagangpedagang dari Hadramaut Semenanjung Arab, Yaman Selatan. Mulanya kesenian ini dijadikan sebagai sarana dalam penyebaran agama Islam di kota Pontianak. Seiring perkembangan zaman kesenian ini dijadikan sebagai tontonan untuk mengibur para penonton. Dalam kesenian Hadrah terkandung beberapa nilai antara lain, keindahan, moral dan religius. Melalui nilai yang terkandung dalam kesenian Hadrah dapat membentuk manusia beriman dan bertakwa kepada Allah Subhanahu Wa Ta'ala, berakhlak mulia sesuai suri tauladan Nabi Muhammad Shallallahu Alaihi Wasallam, serta menjadi warga negara yang baik.
\end{abstract}

Kata kunci: Nilai, Kesenian Hadrah

\begin{abstract}
This study describes the values contained in Hadrah art in Pontianak, West Kalimantan. Hadrah is closely related to Islamic art because the poetry that is sung contains praise for the Creator and Prophet Muhammad Sallallahu Alaihi Wasallam and advice. Using qualitative research methods with an anthropological approach. Data collection techniques used interviews, observation, literature study and data validity testing by extending observations and triangulation. Based on the data analysis, it can be concluded that Hadrah art has existed in Pontianak since the 17th century. This art was brought by traders from Hadramaut Arabian Peninsula, South Yemen. Initially this art was used as a means of spreading Islam in the city of Pontianak. Along with the development of the times this art is used as a spectacle to entertain the audience. In Hadrah art there are several values, among others, the value of truth, beauty, morals and religion. Through the values contained in the art of Hadrah, it can form human beings who believe and fear Allah Subhanahu Wa Ta'ala, have noble character according to the example of the Prophet Muhammad Sallallahu Alaihi Wasallam, and become good citizens.
\end{abstract}

Keywords: Values, Hadrah Art

\section{PENDAHULUAN}

Kalimantan Barat khususnya Kota Pontianak merupakan sebuah wilayah yang memiliki banyak tradisi dan kebudayaan, sehingga memiliki kebudayaan yang beranekaragam. Keanekaragaman kebudayan yang ada di Pontianak tidak terlepas dari adanya kesenian. Kesenian ini ada yang berasal dari masyarakat setempat dan adapula yang mendapat pengaruh dari kebudayaan asing. Kesenian yang mendapat pengaruh budaya asing tersebut mengalami proses, akulturasi, asimilasi atau difusi kebudayaan yaitu kebudayaan asing sebagai pembawa dan kebudayaan Pontianak sebagai penerima. Akulturasi adalah istilah yang diperkenalkan oleh Redfield, Linton dan Herskovitz lewat disiplin ilmu antropologi (dalam Berry, 2005:679-712). Akulturasi merupakan fenomena yang terjadi ketika kelompok- 
kelompok individu memiliki budaya berbeda kemudian saling melakukan interaksi sehingga mengalami perubahan terus menerus. Perubahan ini berjalan beriringan dengan polapola budaya asal dari kelompok itu sendiri atau dari kedua kelompok tersebut. Dapat disimpulkan bahwa akulturasi adalah sebagai proses belajar dari individu yang memasuki budaya baru yang berbeda dari budaya yang telah dimilikinya (Berry, 2005). Begitu pula yang terjadi di kota Pontianak. Berbagai kebudayaan asing yang berakulturasi dengan kesenian Pontianak adalah kebudayaan Arab, dan Tionghoa.

Menurut Alqadrie (dalam Effendi, 2011:119) bahwa manusia di tempat kebudayaan itu hidup, seharusnya mampu merencanakan dan mengontrol perbuatan dan lingkungannya lewat ide atau pemikirannya yang selalu berkembang. Ini berarti bahwa budaya tidak dapat dipisahkan dengan manusia atau masyarakat pendukung atau yang ada disekitarnya. Masyarakat Kalimantan Barat di masa lalu adalah masyarakat yang terbuka. Mereka terbuka terhadap kemungkinan masuknya nilai-nilai luar dalam kehidupan kebudayaan mereka. Kebudayaan selalu berada dalam proses tarik menarik antara nilainilai lama dan nilai-nilai baru. Koentjaraningrat (2015:164-165) berpendapat bahwa ada tujuh unsur kebudayaan yang dapat ditemukan pada semua bangsa di dunia, yaitu bahasa, sistem Pengetahuan, organisasi sosial, sistem peralatan hidup dan teknologi, sistem mata pencaharian hidup, sistem religi, dan kesenian.

Kesenian Hadrah merupakan satu diantara kesenian tradisional di daerah Kalimantan Barat. Hardrah tumbuh dan berkembang pada saat Indonesia mendapat pengaruh agama Islam sebagai agama baru di kalangan masyarakat. Kesenian Hadrah masih ada dan eksis sampai saat ini. Hadrah merupakan kesenian yang berasal dari negeri Arab yang diiringi musik Terbang/Tar/Tahar dan kemudian alat musik ini menjadi ciri khas pengiring musik dalam suku Melayu di kota Pontianak. Hadrah dibawa oleh para pedagang dari Yaman dan di sebarkan kaum ulama untuk melakukan dakwah dalam menyebarkan agama Islam ke daerah-daerah Kalimantan Barat khususnya kota Pontianak.

Kesenian Hadrah pada umumnya di Kalimantan Barat dan khususnya di Pontianak tidak diketahui secara pasti awal mula kemunculannya, sebab tidak ada catatan atau sumber tertulis yang membuat tentang itu. Menurut Syarief Selamat Joesoef Al-Kadrie dan Anwar Dja'far munculnya Hadrah di Kota Pontianak yaitu saat Sultan Muhammad berjaya sekitar tahun 1938 atau 1939. Namun sulit untuk dipastikan siapa yang membawa dan memperkenalkan Hadrah di Pontianak. Tetapi Hadrah sudah ada semenjak jaman kerajaan Kesultanan Pontianak pada tahun 1771 dan menyebar ke daerah-daerah di Kalimantan Barat.

Hadrah secara umum dapat didefinisikan sebagai suatu jenis nyanyian yang berasal dari dzikir, dengan lantunan syair yang memuji kebesaran Allah swt dan Nabi Muhammad saw. Dinyanyikan dengan diiringi alat musik yang disebut tar atau Terbang yang dikemas seindah mungkin untuk meningkatkan kecintaan masyarakat terhadap kebesaran Allah SWT dan Nabi Muhammad SAW. Pujian tentang kebesaran Allah swt dan Rasul-Nya serta perintah dan larangan juga peringatan dikumandangkan lewat Hadrah oleh masyarakat Melayu di Pontianak.

Awal mula munculnya Hadrah hanya berupa lantunan syair yang diiringi oleh 3 pemain musik Tar yang saling mengisi satu dengan yang lain atau biasa dikenal dengan meningkak. Permainan musik dan lantunan syair tersebut dinamakan dengan Zikir Hadrah. Kesenian Hadrah dimulai dengan para pemain duduk bersila menggunakan pakaian tertutup atau gamis, dan melafaskan kalimat "Lailahaillahllah". Kemudian satu diantara pemain melihat gerakan-gerakan yang dilakukan pemain lainya. Maka timbul ide untuk membuat gerakan lebih indah yang berbentuk tari. Dari ide tersebut, maka masyarakat pada saat itu menamakannya seni Hadrah.

Zikir Hadrah berbeda dengan seni Hadrah. Zikir Hadrah berisi tentang lantunan syair-syair yang berisi pujian-pujian terhadap Allah SWT dan Nabi Muhammad SAW, sedangkan seni Hadrah berupa tarian Radat dengan iringan tar dan lantunan pujian-pujian terhadap Allah swt dan Nabi Muhammad SAW. Gerakan yang digunakan sangat sederhana yaitu gerak yang mencerminkan aktivitas sehari-hari, seperti gerak saat orang mengumandangkan azan, mengambil air 
berwudu, shalat (duduk tahiyat), dan beberapa gerakan silat (bunga-bunga).

Adapun yang menjadi alasan peneliti mengkaji lebih lanjut mengenai kesenian Hadrah karena erat dengan nilai-nilai yang terkandung di dalamnya. Menurut Zakiyah dan Rusdiana (2014:15) nilai adalah segala sesuatu yang berhubungan dengan tingkah laku manusia mengenai baik atau buruk yang dapat diukur oleh agama, tradisi, etika, moral, dan kebudayaan yang berlaku dalam masyarakat. Seperti yang telah dipapar sebelumnya bahwa kesenian ini awalnya menjadi media sebagai dakwah dan penyebaran agama Islam di Indonesia khususnya kota Pontianak, tentu memiliki nilai, kedudukan dan fungsi tersendiri dalam masyarakat khususnya di kota Pontianak.

Menurut Soedarsono (2010:123) fungsi seni pertunjukan adalah sebagai sarana ritual, hiburan pribadi dan presentasi estetis atau dipertontonkan. Sejalan dengan pendapat tersebut, kesenian Hadrah berfungsi sebagai sajian yang di pertontonkan. Kesenian Hadrah dalam perkembangannya tidak hanya sebagai media dakwah. Hal ini dikarenakan Hadrah tidak hanya dibawakan dalam acara hari-hari besar agama Islam seperti Maulud Nabi, akan tetapi dapat pula ditampilkan pada hajatan khitanan, perkawinan, khatam Al-qur'an, atau selamatan pindah rumah.

\section{METODE}

Metode yang digunakan dalam penelitian ini adalah penelitian deskriptif untuk menjabarkan nilai-nilai yang terkandung di dalam kesenian Hadrah di Kota Pontianak yang berupa pendeskripsian menggunakan kata-kata dan gambar. Hal tersebut diperkuat oleh pendapat Moleong (2013:11) metode deskriptif adalah penelitian untuk mendeskripsikan data yang dikumpulkan berupa kata-kata, gambar, dan bukan angkaangka. Hal itu disebabkan oleh adanya penerapan metode kualitatif. Dari penjelasan di atas alasan peneliti menggunakan metode deskriptif dengan mengingat data yang dikumpulkan lebih banyak melacak data non angka, misalnya saat informan sedang menceritakan tentang objek penelitian, peneliti mendapat data yang dapat dicatat dan selanjutnya mencoba memusatkan perhatian pada masalah yang diteliti.
Penelitian ini menggunakan pendekatan antropologi. Menurut Suyono (dalam Nurmasnsyah, Rodliyah dan Hapsari, 2019:1) Antropologi berasal dari dua kata Yunani yaitu anthropos, artinya "orang" atau "manusia"; dan logos, artinya "ilmu/nalar". Jadi antropologi adalah ilmu yang memperlajari tentang manusia. Antropologi dapat diartikan sebagai suatu ilmu tentang makhluk manusia dengan mempelajari sifat-sifat manusia berdasarkan aneka warna bentuk fisik, kepribadian, masyarakat, serta kebudayaannya. Kajian antropologi menempatkan manusia yang memiliki karakteristik unik dalam suatu lingkungan hidup yang lebih bermartabat.

Sumber data utama dalam penelitian ini adalah informan, melalui hasil wawancara terhadap pihak-pihak yang berkaitan dan mengetahui tentang nilai-nilai dalam kesenian Hadrah di Kota Pontianak. Teknik Snowball sampling digunakan peneliti untuk mencari beberapa sumber data. Menurut Sugiyono (2015:300) Snowball sampling adalah teknik pengambilan sumber data yang pada awalnya sedikit, lama-lama menjadi besar. Hal ini dilakukan karena sumber data yang sedikit belum dapat memberikan data yang lengkap, sehingga diperlukan sumber data lain untuk menambah informasi terkait penelitian yang dilakukan.

Adapun narasumber dalam penelitian ini adalah Anwar Dja'far (47 tahun) yang mengetahui kesenian Hadrah pemain hadrah pada grup Hadrah Hubbul Wathon di daerah Sungai Jawi, serta dan Ustad Ma'arif Muhammad Arif (68) beliau adalah tokoh Hadrah senior di Kota Pontianak. Teknik dalam mengumpulkan data menggunakan wawancara, observasi dan studi pustaka. Kemudian diuji keabsahan datanya menggunakan Triangulasi. Menurut Sugiyono (2018:372-373) triangulasi adalah teknik pengecekan kredibilitas data dengan berbagai teknik pengumpulan data dan berbagai sumber data. Lebih lanjut Sugiyono memaparkan bahwa triangulasi terbagi menjadi tiga jenis yaitu teknik, sumber dan waktu. Adapun yang digunakan dalam mengecek keabsahan data pada penelitian ini adalah triangulasi sumber, yaitu menguji kreadibilitas data dengan melakukan cek data yang telah diperoleh sebelumnya dari beberapa sumber kemudian dianalisis serta disimpulkan, 
Volume 12 | Number 1| April |2021, Page 1-6/ E-ISSN: 2715-1247 dan P-ISSN: 2087-84xx

kemudian selanjutnya dimintakan kesepakatan dengan beberapa sumber data tersebut.

\section{HASIL DAN PEMBAHASAN}

Hadrah merupakan kesenian yang berasal dari Yaman Selatan tepatnya di Hadramaut Semenanjung Arab. Hadrah sangat erat kaitannya dengan agama Islam. Oleh karena itu kesenian Hadrah menjadi sebuah kesenian yang bernafaskan Islam. Sejarah masuknya Hadrah di Kota Pontianak bersamaan dengan masuknya Agama Islam di Pontianak, diperkirakan sekitar tahun 1741M. Ulama yang pertama kali membawa Islam ke Kalimantan Barat adalah Syarief Husein Al Kadri.

Hadrah adalah seni dzikir yang menjadi strategi Syarief Husein Al Kadri dan anaknya Sultan Syarief Abdurrahman Al Kadri untuk menyebarkan agama Islam di kota Pontianak. Seni dzikir ini berisi Syair-syair/ Qasidah yang memuji Kebesaran Allah AWT dan mengagungkan Nabi Muhammad SAW, syair tersebut diambil dari Kitab Maulud.

Adapun terdapat nilai-nilai yang terkandung di dalam kesenian Hadrah, antara lain nilai keindahan, moral dan religius. nilainilai ini tergambar dari syair yang dilantunkan, gerakan, serta fungsi dari kesenian Hadrah itu sendiri. Fungsi tersebut adalah sebagai penyebaran agama Islam, yang sekarang berkembang menjadi seni pertunjukan.

Nilai keindahan terdapat dalam pertunjukan kesenian Hadrah. Bentuk penyajian kesenian Hadrah di Kota Pontianak disesuaikan pada setiap acara. Misalnya saat ditampilkan pada Istana Kadriah akan ada perbedaan pada acara hajatan di rumah-rumah warga, serta penampilan di atas panggung (penyajian secara estetis). Adapun, dikarenakan Hadrah merupakan dzikir dengan melantunkan syair bernafaskan Islam, alat musik yang mengiringi kesenian ini pula adalah hasil akulturasi antara negeri Yaman dengan Pontianak. Alat musik tersebut dinamai dengan Tar atau Terbang yang berbentuk bulat pipih melingkar yang memiliki membran atau kulit pada satu diantara permukaan lingkarannya serta memiliki kerincing (alat bunyi-bunyian dibuat dari logam) ditiga titik pinggir alat musik tersebut dan dimainkan dengan cara dipukul.

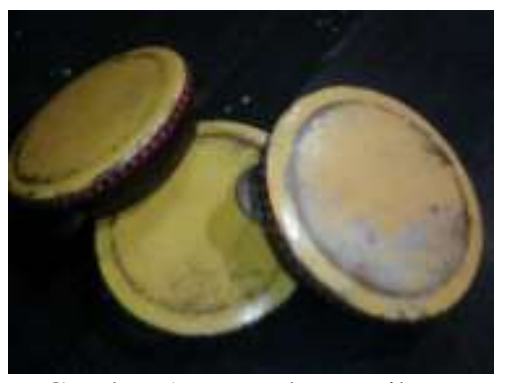

Gambar 1. Foto alat musik tar

Kemudian kesenian Hadrah mengalami perkembangan dengan penambahan gerak tari atau yang biasa disebut dengan tari Radat. Gerakan yang ada di dalam kesenian ini merupakan hasil adaptasi dari gerak keseharian seperti gerak azan, berwudu, shalat, dan bunga-bunga silat.

Busana yang dikenakan adalah baju gamis. Serta posisi dari masing-masing pemain adalah saling berhadapan satu dengan yang lain. Pemain Hadrah dapat terdiri dari 10-20 orang. Dahulu kesenian ini hanya dapat dibawakn oleh laki-laki saja. Seiring perkembangan zaman, perempuan juga dapat membawakannya dengan kaidah-kaidah kesopanan dan menutup aurat.

Keseneian Hadrah sebagai tontonan atau sajian estetis yang bertujuan untuk menghibur para penontonya dikemas dengan sederhana baik dari segi gerak maupun pola lantainya. Pola lantai yang digunakan hanya vertikal dan gerak yang dibawakan dilakukan berulangulang sehingga terkesan monoton. Durasi penampilannya cukup panjang khususnya untuk hajatan dan acara besar Islam bisanya bisa dilakukan semalaman suntuk yang dimulai dari pukul 20.00 sampai masuk zuhur.

Tari Radat dalam kesenian Hadrah memiliki nilai moral satu diantaranya adalah berakhlak mulia seperti yang dicontohkan oleh Nabi Muhammad SAW. Akhlak mulia di sini adalah perilaku, sikap, perbuatan, adab dan sopan santun. Tidak hanya itu saja sikap berani, bertutur lembut, amanah, jujur dan rendah hati merupakan baik dari berakhlak mulia. Akhlak mulia ini tentunya harus sesuai dengan tuntunan Al-Quran dan Hadist.

Nilai moral yang terkandung dalam karya seni, khususnya dalam kesenian Hadrah bertujuan untuk memberikan pengajaran kepada manusia agar mengenal dan menerapkan nilai-nilai etika dan norma yang berlaku dalam masyarakat. Nilai baik buruk suatu perbuatan serta norma yang berlaku berisi tentang pengajaran mengenai perbuatan 
yang dihindari dan harus dikerjakan, sehingga tercipta suatu hubungan manusia dalam masyarakat yang dianggap baik, serasi, dan bermanfaat bagi manusia itu sendiri, masyarakatnya, lingkungan serta alam sekitar. Nilai pendidikan moral pada tari Radat dalam kesenian Hadrah dapat dilihat dari syair yang mengiringi tari Radat.

Syair Sejarah Mi'rajnya Nabi Muhammad saw 4. Jibril dimasa itu berpakaian lengkap Sebanyak enam ratus memakai sayap Memberi hormat berdiri tegak Menghormati Nabi kepada Tuhan menghadap

5. Waktu Nabi sedang berangkat Jibril berpesan sebagai nasehat Kalau Engkau sampai disatu tempat Berilah salam kemudian munajad

6. Sampai Nabi di Hijab dengan selamat Mengucapkan salam dengan ta'dim dan hormat

Beliau sujud memohon rahmat

Salamnya dijawab angkat kepalamu ya Muhammad

8. Ada satu kejadian yang sangat heran Dalam Hijab itu satu pemuda kelihatan Nabi menyangkah Malaikatkah itu atau insan Sebetulnya itu orang yang punya tiga amalan

9. Pertama amalnya banyak ingat kepada Allah Kedua pergi ke masjid mengerjakan shalat Ketiga tak pernah durhaka kepada ibu dan ayah

Dikerjakannya semua itu tulus ikhlas karena Allah

Penggalan syair tersebut mengingatkan kita untuk memiliki kepribadian yang baik. Dengan selalu mengingat Allah, tunduk kepada Allah, melakukan segala perintah-Nya dan menjauhi larangan-Nya, selalu menghormati orang yang lebih tua, selalu memberi salam ketika bertemu seseorang dan selalu menampakkan wajah yang berseri-seri, tulus dan ikhlas karena Allah.

Nilai religius dapat dilihat dari fungsi, gerakan dan syair dalam kesenian Hadrah ini. Pada dasarnya dalam segala kegiatan yang dilakukan oleh manusia hendaknya selalu berhubungan dengan Tuhan. Dalam kesenian ini wujud nilai religus meliputi taqwa, mengingat, menyembah, dan bersyukur kepada Tuhan.

Syair Sejarah kelahiran Nabi (Rasulullah saw):

1. Ada satu riwayat Nabi mengatakan

Aku dahulu dari adam dijadikan

Dua ribu tahun lamanya bertasbih kepada

Tuhan

Diikuti Malaikat apa yang ku ucapkan

2. Waktu Nabi Adam dijadikan Allah

Empat anasir jadi satu lembaga

Aku ditempatkan di sulbinya berada

Hingga aku bersamanya keluar dari Surga

Syair Sejarah hukum Pekeh:

4. Sembahyang lima waktu itulah tiang agama

Dikerjakan dengan baik jangan dilenga

Kalau betul dikerjakan yakin dan sempurna

Allah Lindungi dari bala bencana

12. Adanya Allah tak boleh di ingkari

Malaekat dan kitab, Rasul dan Nabi

Hari qiamat pasti akan terjadi

Untuk baik dan jahat dari Allah sendiri

Dalam penggalan syair tersebut mengandung makna ajakan untuk selalu mengingat Allah dengan berzikir, seperti Nabi yang selalu bertasbih kepada-Nya. Dalam sepenggalan syair ini juga mengajak kita untuk segera bergegas beribadah tanpa melalaikannya, karena perbuatan apa pun yang kita lakukan di dunia, pasti akan diketahui oleh Allah SWT.

Adapun, selain dari penggalan syair, nilai-nilai kebenaran juga dilihat dari gerak tari Radat, dalam kesenian Hadrah yang mencerminkan kehidupan sehari-hari dalam beribadah. Pertama gerak melenggang, gerak ini menggambarkan gerak orang yang sedang berzikir. Melenggangkan badan kekanan dan kiri mengikuti tempo atau ketukan dari musik tar. Gerakan kedua adalah gerakan yang mencerminkan orang yang sedang berwudhu. Wudhu memiliki makna untuk membersihkan tubuh dan hati dari segala kotoran dengan menggunakan air suci. Dalam tari Radat ini tidak semua urutan wudhu yang diambil, gerakan wudhu yang terlihat hanya gerakan mengambil air kemudian membasuh telinga. Gerakan berwudhu ini mengingatkan seluruh insan bahwa sebelum menghadap Allah maka sebagai manusia harus dalam keadaan yang bersih dan bertobat.

Taqwa kepada Allah SWT merupakan sebuah kesadaran yang harus diikuti dan dipatuhi serta taat dalam melaksanakan perintah serta menjauhi segala larangan-Nya. 
Volume 12 | Number 1| April |2021, Page 1-6/ E-ISSN: 2715-1247 dan P-ISSN: 2087-84xx

Dengan memulai pergerakan dari sebelah kanan, bermakna selalu mendahulukan kebaikan. Hal itu menjadi suatu peringatan dan harapan untuk selalu bertakwa kepada Tuhan Yang Maha Esa dan mengutamakan kebaikan. Nilai-nilai religius yang ada dalam karya seni tersebut, khususnya pada kesenian Hadrah dimaksudkan agar baik penikmat ataupun pemain kesenian tersebut mendapatkan pengetahuan bahwa dalam menjalani kehidupan harus berpedoman pada nilai-nilai agama.

\section{SIMPULAN}

Dari penjabaran tersebut dapat disimpulkan bahwa kesenian Hadrah yang mulanya berfungsi sebagai penyebaran Agama Islam di kota Pontianak oleh para pedagang dari Yaman, seiring perkembangan zaman dapat pula berfungsi sebagai tontonan atau penyajian estetis yang di bawakan dalam berbagai acara, seperti hajatan khataman AlQur'an, Mauud Nabi, Khitanan, syukuran dan pindahan rumah. Sebagai kesenian yang telah ada sejak abad 17-an, Hadrah erat akan nilainilai yang terkandung di dalamnya. Nilai tersebut antara lain, nilai keindahan, moral dan religius. Nilai keindahan tercermin pada penyajiannya, sedangkan nilai moral terdapat pada syair dan nilai religius dapat terlihat dari gerakan dan juga syair yang terkandung di dalam kesenian Hadrah.

Adapun yang menjadi saran dalam penelitian ini terutama masyarakat yang berada di kota Pontianak hendaknya mengetahui dan mengamalkan nilai-nilai baik yang terkandung di dalam kesenian yang mereka miliki. Dengan mengetahui dan mengamalkannya maka nilai-nilai baik akan terus berkembang serta tumbuh, sehingga dapat memperkuat karakteristik ketimuran negara Indonesia khususnya kota Pontianak yang terkenal, sopan santun, ramah, berbudi luhur, dan berakhlak mulia.

\section{DAFTAR RUJUKAN}

Berry, Jhon W. (2005). Acculturation : Living successfully in two cultures. International Journal Of Intercultural Relations. Vol. 29: 679-712.

Effendi, Chairil. (2011). Sejarah Penyebaran dan Pengaruh Budaya Melayu di Kalimantan. Jakarta: Direktorat Jenderal Sejarah dan Purbakala Kemenbudpar.

Koentjaraningrat. (2015). Pengantar Ilmu Antropologi. Jakarta: Rineka Cipta.

Nurmansyah, Gunsu, Nunung Rodliyah, Recca Ayu Hapsari. (2019). PENGANTAR ANTROPOLOGI Sebuah Ikhtisar Mengenal Antropologi. Bandar Lampung: Anugrah Utama Raharja

Soedarsono. (2010). Seni Pertunjukan Indonesia Di Era Globalisasi. Yogyakata:Gadjah Mada University Press.

Sugiyono. (2017). Metode Penelitian Kuantitatif Kualitatif Dan $R \& D$. Bandung: Alfabeta

Zakiyah, Qiqi Yuliantini dan Rusdiana. (2014). PENDIDIKAN NILAI Kajian Teori dan Praktik di Sekolah. Bandung: Pustaka Setia. 